\title{
K ANTIGENS OF ESCHERICHIA COLI AND VIRULENCE IN URINARY-TRACT INFECTION: STUDIES IN A MOUSE MODEL
}

\author{
A. M. J. J. VerweiJ-Van Vught, J. F. van den Bosch*, F. Namavar, \\ M. SPARRIUS AND D. M. MACLAREN
}

Laboratory of Medical Microbiology, Free University, van der Boechorst-straat 7, P.O.B. 7161, 1007 MC Amsterdam and *Institute for Epidemiology, Erasmus University, Rotterdam, The Netherlands

\begin{abstract}
SUMmary. The importance of $\mathrm{K}$ antigens of Escherichia coli as virulence factors was studied by comparing groups of mice given either strains of $E$. coli isolated from urinary tract infection in humans or mutant strains differing only in the absence of the $\mathrm{K}$ antigen. $\mathrm{K}$ antigens proved to be of minor importance for mouse nephropathogenicity; however, with the exception of the $\mathrm{K}(\mathrm{A})$ antigen, they contributed substantially to deaths attributed to more general infection. Possible mechanisms for the virulence of strains with $\mathrm{K}$ antigens are discussed in terms of the bactericidal effect of serum and phagocytosis.
\end{abstract}

\section{INTRODUCTION}

Capsular (K) antigens of Escherichia coli have been designated virulence factors because of their ability to prevent bacterial killing by serum and phagocytosis by polymorphonuclear (PMN) leucocytes (Glynn and Howard, 1970; Howard and Glynn, 1971; Rottini et al., 1975; van Dijk et al., 1977; Horwitz and Silverstein, 1980). Information about the importance of $\mathrm{K}$ antigens in the pathogenesis of urinary tract infections is somewhat contradictory. $\mathrm{K}$ antigens occurred more frequently in strains of $E$. coli causing pyelonephritis than in strains isolated from acute cystitis or from the faeces of healthy persons in some studies (Kaijser, 1973), but not in others (Kalmanson, 1975; van den Bosch et al., 1980). The frequency of occurrence and the amount of $\mathrm{K}$ antigens have been associated with virulence for the urinary tract in epidemiological studies (Glynn, Brumfitt and Howard, 1971; Kaijser, 1973; McCabe et al., 1975) and in an experimental mouse model, in which an ascending route of infection was used (Kalmanson et al., 1975; Nicholson and Glynn, 1975). The amount of $\mathrm{K}$ antigen proved to be especially important for renal involvement (Glynn et al., 1971; Nicholson and Glynn, 1975). The experiments reported here were designed to investigate the importance of $\mathrm{K}$ antigens for urinary tract infection in an experimental mouse model (van den Bosch, de Graaff and MacLaren, 1979) by comparing isogenic $E$. coli strains differing only in the presence of $\mathrm{K}$ antigen. 


\section{MATERIALS AND METHODS}

Bacterial strains. Six strains of $E$. coli were isolated from the urine of patients with urinary tract infection. Diagnosis was based on clinical assessment, a distinction being made between acute pyelonephritis, acute cystitis and asymptomatic bacteriuria (Freedman, 1979). The methods for biotyping and serotyping of the strains have been described previously (van den Bosch et al., 1980). Their properties are listed in table II.

Detection of $\mathrm{K}^{-}$mutants by slide agglutination. $\mathrm{K}^{-}$mutants were isolated by testing colonies from 18-h cultures on nutrient agar in a slide agglutination test with $\mathrm{O}$-antisera. Colonies that gave a strongly positive reaction were subcultured and their identity confirmed by the tube agglutination test and immunoelectrophoresis.

Tube agglutination test. Bacteria grown on nutrient agar for $18 \mathrm{~h}$ were suspended in phosphate buffered saline (PBS) to a concentration of $5 \times 10^{8} \mathrm{cfu} / \mathrm{ml}$. Strains with thermostable $\mathrm{K}(\mathrm{A})$ antigens were heated for $2 \mathrm{~h}$ at $120^{\circ} \mathrm{C}$ to destroy the $\mathrm{K}$ antigen. Other strains were boiled for $1 \mathrm{~h}$. The suspensions of live or heated bacteria were mixed with equal amounts $(100 \mu \mathrm{l})$ of serial dilutions of the O-antiserum in PBS in a Multiwell Disposotray with a well capacity of $1 \mathrm{ml}$ (Flow Laboratories, Hamden, CT, USA). The agglutination was examined after overnight incubation at $37^{\circ} \mathrm{C}$.

Immunoelectrophoresis was done as described by Scheidegger (1955) with extracts prepared as described by Ørskov et al. (1971).

Antisera. O-antisera were obtained from Difco Laboratories (Detroit, MI, USA). K1 strains were typed by slide agglutination with Neisseria meningitidis group B antiserum (Difco). The antisera for the electrophoresis experiments were obtained from rabbits given four intravenous injections of $\mathrm{K}^{+}$bacteria with 5 days between injections. The first two injections $(0.25$ and $0.5 \mathrm{ml})$ contained formalin-killed bacteria $\left(1 \times 10^{8} \mathrm{cfu} / \mathrm{ml}\right)$, and the last two $(1 \mathrm{ml}$ each $)$ contained live bacteria $\left(2 \times 10^{8}\right.$ and $1 \times 10^{9} \mathrm{cfu} / \mathrm{ml}$ respectively). About 5 days after the last injection the rabbits were bled.

Virulence for mouse kidney. The virulence of the strains was tested in a modification of the mouse model (van den Bosch et al., 1979), which measured the viable counts in kidneys, liver, blood and spleen of the mice up to $8 \mathrm{~h}$ after intravenous injection of $2 \times 10^{8}$ bacteria. Three patterns of infection have been described in this model, which enable strains to be classified into three groups. In group I the viable counts fell and remained low in the kidney and in other organs; in group II the vjable counts fell and then rose after $4 \mathrm{~h}$ in the kidney but not in other organs, suggesting that group II strains are virulent for the mouse kidney; in group III, viable counts were high in the kidney and in other organs suggesting more general infection. In our modification, six mice were given injections of each strain. Kidney counts only were made in duplicate at 3 and $8 \mathrm{~h}$ after injection. The two remaining mice were killed after 14 days.

LD50 determination. LD50 values were measured as described by van den Bosch et al. (1979). The LD50 values were calculated by the method of Spearman and Kärber (Finney, 1964).

Serum resistance. The bactericidal effect of serum was estimated by the method of Taylor, Roberts and Gower (1972). Log-phase cells were diluted in $0.05 \mathrm{M}$ Tris- $\mathrm{HCl}$ buffer, $p \mathrm{H} 8.4$, to a density of $10^{3} \mathrm{cfu} / \mathrm{ml}$. A $0.5 \mathrm{ml}$ volume of this suspension was added to $1.5 \mathrm{ml}$ of $20 \%(\mathrm{v} / \mathrm{v})$ pooled normal human serum and incubated for $3 \mathrm{~h}$ in a shaking water bath at $37^{\circ} \mathrm{C}$. Viable bacteria were measured after incubation for $0,1,2$ and $3 \mathrm{~h}$.

Preparation of polymorphonuclear (PMN) leucocytes. Venous blood was obtained from normal healthy donors. The leucocyte suspension was prepared by sedimentation of heparinised venous blood in dextran $6 \%(\mathrm{w} / \mathrm{v})$ in saline. The leucocytes were washed twice in

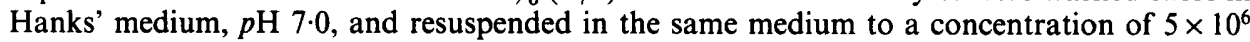
leucocytes $/ \mathrm{ml}$.

Chemiluminescence of PMN leucocytes. The chemiluminescence (CL) of leucocytes was measured in the presence of luminol, which is known to enhance it (Ewetz, Palmblad and Thore, 1979). Log-phase bacteria $\left(5 \times 10^{7} \mathrm{cfu} / \mathrm{ml}\right)$ were mixed with pooled normal human serum $(40 \%$ $\mathrm{v} / \mathrm{v})$, leucocytes $\left(5 \times 10^{6} / \mathrm{ml}\right)$ and luminol $\left(10^{-4} \mathrm{M}\right)$ in equal volumes, which gave a bacteria: leucocyte ratio of 10:1. These mixtures were incubated in Lumacuvette-P tubes in a shaking water bath at $37^{\circ} \mathrm{C}$; every $5-10 \mathrm{~min}, \mathrm{CL}$ was measured in a Lumacounter ${ }^{\mathrm{TM}} \mathrm{M} 2080$ (Lumac Systems 
A.G., Basel, Switzerland). The amount of $C L$ was calculated as the mean of the counts after 10 , 20,30 and $40 \mathrm{~min}$.

Growth rate determination. Growth rates were determined by calculating the generation time of the bacteria during the logarithmic phase of growth in nutrient broth. The numbers of bacteria were determined by viable counts.

Haemolysin production. Haemolysis was tested on washed-blood agar plates. Defibrinated sheep blood (Gibco, Glasgow, Scotland) was washed three times in PBS and added to Blood Agar Base No. 2 (Oxoid) to a final concentration of $5 \%$. Haemolysis was read after overnight incubation at $37^{\circ} \mathrm{C}$.

Haemagglutination (HA) tests. Type I pili that produce mannose sensitive HA (MSHA) are best developed in broth culture at $37^{\circ} \mathrm{C}$ whereas non-type I pili that produce mannose resistant HA (MRHA) are best developed on agar plates at $37^{\circ} \mathrm{C}$; both can be demonstrated at $3-5^{\circ} \mathrm{C}$. To test the HA patterns, bacteria were grown for $18 \mathrm{~h}$ in nutrient broth with very gentle agitation, or on washed-blood agar plates at $37^{\circ} \mathrm{C}$, and resuspended in PBS to a concentration of $10^{9} \mathrm{cfu} / \mathrm{ml}$ as judged by optical density at $650 \mathrm{~nm}$. Guinea pig blood (Albino, random bred) and human group A blood were collected into Alsever solution ( $1: 1)$; blood cells were washed three times with PBS and suspended to a final concentration of $0.5 \%$. Bacterial and erythrocyte suspensions ( $100 \mu \mathrm{l}$ of each) were mixed in wells of a Multiwell Disposotray with a well capacity of $1 \mathrm{ml}$ (Flow Laboratories). For testing the mannose-sensitivity of the HA, assays in the presence of D-mannose 0.5\% were included. Agglutination was read after incubation for $2 \mathrm{~h}$ at $0-4 \mathrm{C}$, after agitation.

Antibiotic sensitivity was determined by an agar diffusion method using Neo-Sensitabs (Rosco, Taastrup, Denmark) and Isosensitest agar (Oxoid).

\section{RESULTS}

\section{Isolation of $\mathrm{K}^{-}$mutants of $\mathrm{E}$. coli}

$\mathrm{K}^{-}$mutants of strains AD35 and AD36 were isolated from the urine of rats that developed chronic pyelonephritis after experimental infection with the parent strains. Mutants of strains AD307, AD311 and AD412 were isolated as sectors of colonies with a slightly more translucent appearance on nutrient agar plates. Strain AD121 showed no variation in colonial morphology and c. 300 colonies were tested for the absence of $\mathrm{K}$ antigen by slide agglutination; one colony was identified and subcultured. All colonies (one to five per strain) that gave a strongly positive slide agglutination reaction with $\mathrm{O}$-antiserum were compared with their parent strains in a tube agglutination test (table $\mathrm{I}$ ). In tests with live $\mathrm{K}^{+}$strains, the $\mathrm{K}$ antigen inhibited

TABLE I

Agglutination titres of live and heat-treated bacteria with $O$-antisera

\begin{tabular}{|c|c|c|c|c|}
\hline \multirow[b]{3}{*}{ Strain } & \multicolumn{4}{|c|}{$\begin{array}{l}\text { Titres obtained with O-antiserum and } \\
\text { preparations of the given strain }\end{array}$} \\
\hline & \multicolumn{2}{|c|}{$\mathrm{K}^{+}$parent strain } & \multicolumn{2}{|c|}{$\mathrm{K}^{-}$mutant strain } \\
\hline & Live cells & Heat-treated cells* & Live cells & Heat-treated cells \\
\hline $\begin{array}{l}\text { AD35 } \\
\text { AD36 } \\
\text { AD121 } \\
\text { AD307 } \\
\text { AD311 } \\
\text { AD412 }\end{array}$ & $\begin{array}{l}<2 \\
<2 \\
<2 \\
<2 \\
<2 \\
<2\end{array}$ & $\begin{array}{r}128 \\
128 \\
128 \\
128 \\
64 \\
256\end{array}$ & $\begin{array}{c}128 \\
128 \\
128 \\
64 \\
64 \\
256-512\end{array}$ & $\begin{array}{c}128 \\
128-256 \\
128 \\
128 \\
128 \\
256\end{array}$ \\
\hline
\end{tabular}

* Strains with $\mathrm{K}(\mathrm{A})$ antigens were heated for $2 \mathrm{~h}$ at $120^{\circ} \mathrm{C}$; other $\mathrm{K}^{+}$strains were heated at $100^{\circ} \mathrm{C}$ for $1 \mathrm{~h}$. 
agglutination with $\mathrm{O}$-antisera. In contrast, similar titres were obtained in tests with heated $\mathrm{K}^{+}$strains and heated or unheated $\mathrm{K}^{-}$mutants. With strains AD35 and AD412, three and two stable $\mathrm{K}^{-}$mutants respectively were isolated. The results of the tube agglutination tests with different mutants of the same strain were similar and only the results for one mutant of each strain are given in table I.

The absence of $\mathrm{K}$ antigen in four of the mutants (AD36, AD121, AD307 and AD311) was confirmed by immunoelectrophoresis with rabbit antisera prepared against whole $\mathrm{K}^{+}$bacteria. No line was seen with $\mathrm{K}^{-}$mutants at the position of the $\mathrm{K}$-precipitation line seen with $\mathrm{K}^{+}$parent strains. With strain $\mathrm{AD} 35$, no difference in precipitation lines was observed indicating that $\mathrm{K}$ antibodies were not present in the rabbit antiserum.

Absence of the $\mathrm{K} 1$ antigen in the $\mathrm{K}^{-}$mutant of strain AD412 was confirmed by a negative result in the slide agglutination test with Neisseria meningitidis group B antiserum.

The mutant strains were tested for biotype, antibiotic sensitivity pattern, haemolysis, haemagglutination pattern and growth rate. No differences were observed between parent and mutant strains in any of the characters tested.

\section{Virulence for mouse kidney}

The virulence of $\mathrm{K}^{+}$and $\mathrm{K}^{-}$strains was tested in a mouse model (van den Bosch et al., 1979). Bacterial counts in the kidney at 3 and $8 \mathrm{~h}$ after injection enabled the strains to be divided into the three distinct groups (see table II). For three group II strains, there were no differences in the virulence of the $\mathrm{K}^{-}$mutants. For three group III strains, however, the $\mathrm{K}^{-}$mutants were less virulent than the parent strains; two of these were now classified as group I and one as group II. This was accompanied by an

TABLE II

Results of virulence and chemiluminescence assays with $\mathrm{E}$. coli strains and $\mathrm{K}$-negative mutants

\begin{tabular}{|c|c|c|c|c|c|c|c|c|}
\hline \multirow{2}{*}{$\frac{\text { Strain }}{\text { AD35 } \mathbf{K}_{\mathbf{K}^{+}}^{+}}$} & \multirow{2}{*}{$\frac{\text { Source* }}{\text { ABU }}$} & \multirow{2}{*}{$\begin{array}{l}\text { Serotype } \\
\text { O6K?H1 } \\
\text { O6K }-\mathrm{H} 1\end{array}$} & \multirow{2}{*}{$\begin{array}{c}\text { Haemolysis } \\
- \\
-\end{array}$} & \multirow{2}{*}{$\begin{array}{l}\begin{array}{c}\text { Virulence } \\
\text { groupt }\end{array} \\
\text { III }\left(\begin{array}{r}1 \\
\text { I }\end{array}\right) \S \\
(14 \mathrm{~d})\end{array}$} & \multirow{2}{*}{$\begin{array}{c}\begin{array}{c}\text { LD50 value } \\
\left(\mathrm{cfu} \times 10^{7}\right)\end{array} \\
13 \cdot 3\left(\begin{array}{c}9 \cdot 2-19 \cdot 1) \| \\
18 \cdot 9(15 \cdot 0-23 \cdot 7)\end{array}\right.\end{array}$} & \multicolumn{3}{|c|}{$\begin{array}{l}\text { Chemiluminescence } \\
\text { ratio }\left(\mathrm{K}^{+} / \mathrm{K}^{-}\right) \ddagger\end{array}$} \\
\hline & & & & & & 0.79 & $0 \cdot 82$ & 0.71 \\
\hline$\underset{\mathrm{K}^{-}}{\mathrm{AD} 36 \mathrm{~K}^{+}}$ & $\mathrm{C}$ & $\begin{array}{l}\mathrm{O} 6 \mathrm{~K}^{2} \mathrm{H} 1 \\
\mathrm{O}^{-} \mathrm{K}^{-} \mathrm{H} 1\end{array}$ & $\begin{array}{l}+ \\
+\end{array}$ & $\begin{array}{l}\text { II }(<8 \mathrm{~h}-1 \mathrm{~d}) \\
\text { II }(<8 \mathrm{~h})\end{array}$ & $\left.\begin{array}{r}5 \cdot 2(2 \cdot 9-9 \cdot 4) \\
16 \cdot 8(11 \cdot 7-24 \cdot 0)\end{array}\right\}$ & $0 \cdot 55$ & 0.62 & 0.66 \\
\hline$\underset{\mathrm{K}^{-}}{\mathrm{AD} 121} \mathrm{~K}^{+}$ & $\mathrm{C}$ & $\begin{array}{l}\mathrm{O} 6 \mathrm{~K}^{2} 23 \mathrm{H1} \\
\mathrm{O}^{-} \mathrm{Kl}\end{array}$ & $\begin{array}{l}+ \\
+\end{array}$ & $\begin{array}{l}\text { III }(<8 h) \\
\text { II }(3 \mathrm{~d})\end{array}$ & $\begin{array}{r}2 \cdot 1\left(\begin{array}{r}1 \cdot 4-3 \cdot 3) \\
27 \cdot 1(21 \cdot 6-34 \cdot 0)\end{array}\right\}\end{array}$ & 0.55 & 0.76 & 0.95 \\
\hline$\underset{\mathrm{K}^{-}}{\mathrm{AD} 307 \mathrm{~K}^{+}}$ & $P$ & $\begin{array}{l}\mathrm{O} 8 \mathrm{~K}(\mathrm{~A}) ? \mathrm{H} 19 \\
\mathrm{O}^{-} \mathrm{K}^{-} \mathrm{H} 19\end{array}$ & $\begin{array}{l}- \\
-\end{array}$ & $\begin{array}{l}\text { II }(14 d) \\
\text { II }(14 d)\end{array}$ & $\left.\begin{array}{l}34.1(21.6-53 \cdot 7) \\
29.7(17 \cdot 9-49 \cdot 4)\end{array}\right\}$ & 0.17 & 0.49 & 0.13 \\
\hline $\operatorname{AD} 311 \underset{\mathrm{K}^{-}}{\mathrm{K}^{+}}$ & $\mathrm{P}$ & $\begin{array}{l}\mathrm{O} 8 \mathrm{~K}(\mathrm{~A}) 28 \mathrm{H}^{-} \\
\mathrm{O}^{-} \mathrm{K}^{-} \mathrm{H}^{-}\end{array}$ & $\begin{array}{l}- \\
-\end{array}$ & $\begin{array}{l}\text { II }(7-14 d) \\
\text { II }(14 d)\end{array}$ & $\left.\begin{array}{l}16 \cdot 8(11 \cdot 7-24 \cdot 0) \\
18 \cdot 3(11 \cdot 3-29 \cdot 7)\end{array}\right\}$ & 0.06 & $0 \cdot 10$ & $0 \cdot 11$ \\
\hline$\underset{\mathrm{K}^{-}}{\mathrm{AD} 412 \mathrm{~K}^{+}}$ & $\mathrm{C}$ & $\begin{array}{l}\text { O7K } 1 \mathrm{H}^{-} \\
\mathrm{O}^{-} \mathrm{K}^{-} \mathrm{H}^{-}\end{array}$ & $\begin{array}{l}- \\
-\end{array}$ & $\begin{array}{l}\text { III }(<8 \mathrm{~h}) \\
\text { I }(2-14 \mathrm{~d})\end{array}$ & $\left.\begin{array}{r}2.3(1.4-3.7) \\
32.4(23.6-44.6)\end{array}\right\}$ & 0.24 & $0 \cdot 28$ & 0.26 \\
\hline
\end{tabular}

\footnotetext{
* ABU: asymptomatic bacteriuria, P: pyelonephritis, $\mathrm{C}$ : cystitis;

† Group I, avirulent; II, mouse nephropathogenic; III, virulent;

$\$$ Ratios for three separate experiments;

$\S$ Time of death after injection of bacteria;

II Upper and lower limits of LD50 values $(p=0.05)$.
} 
increased survival time of the mice. The mutant strains did not revert to the $\mathrm{K}^{+}$ phenotype during passage through the mice.

\section{LD50 determination}

No differences in LD50 values were observed between the group II strains AD307 and AD311 and their $\mathrm{K}^{-}$derivatives (table II). Strain AD36 showed an increased LD50, without a change in the behaviour pattern in the mouse kidney. Two of the group III strains (AD121 and AD412) showed a significant increase $(p<0.05)$ in LD50 values of the $\mathrm{K}^{-}$strains; the increase with strain AD35 was not significant and all three strains showed a reduction in virulence.

\section{$K$ antigens and serum resistance}

All $\mathrm{K}^{+}$and $\mathrm{K}^{-}$strains were tested for sensitivity to killing in $15 \%$ pooled normal human serum (figs 1 and 2). All $\mathrm{K}^{+}$strains were resistant to serum and grew in the

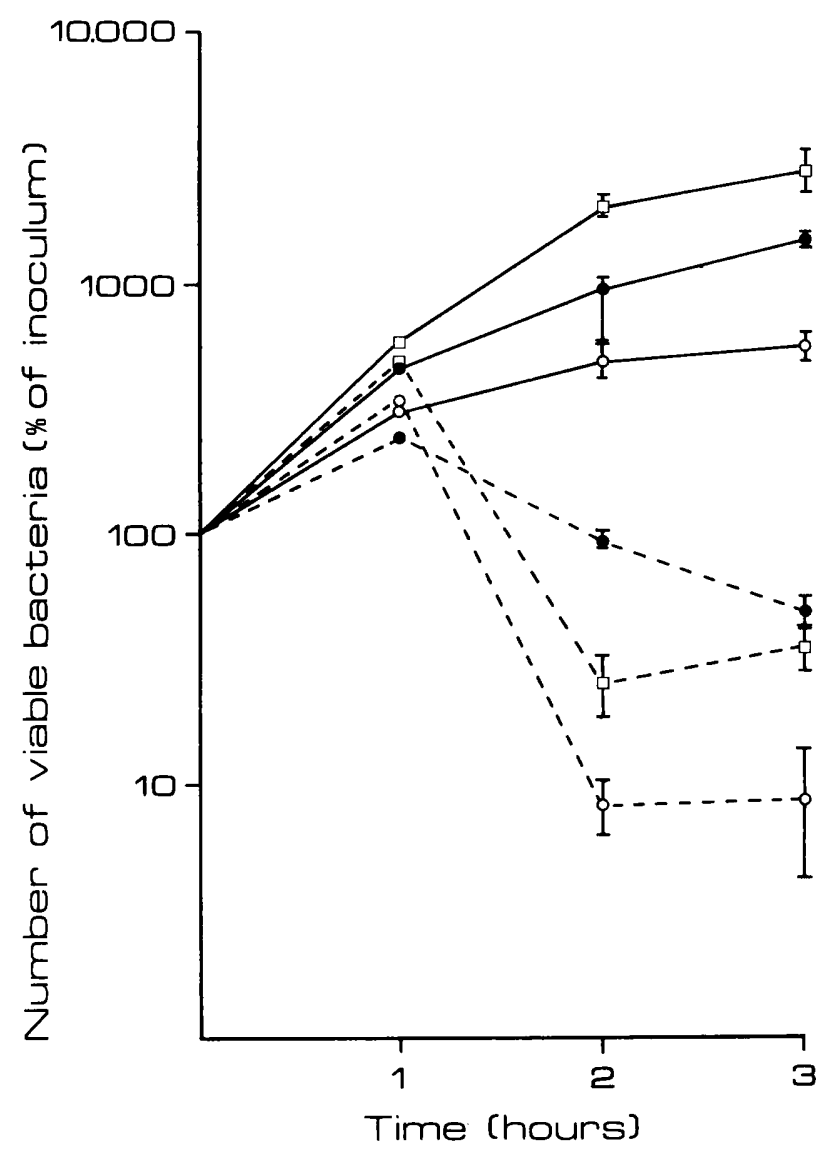

FIG. 1.-Sensitivity of group II E. coli $\mathrm{K}^{+}$strains and their $\mathrm{K}^{-}$mutants after incubation with $15 \%$ normal pooled human serum. - - $\mathrm{K}^{+}$strains; - - - $\mathrm{K}^{-}$strains; $-\longrightarrow:$ AD36; $\bigcirc-\mathrm{O}:$ AD307; $\square$ - AD311. Bars represent the standard deviation of the viable count. 


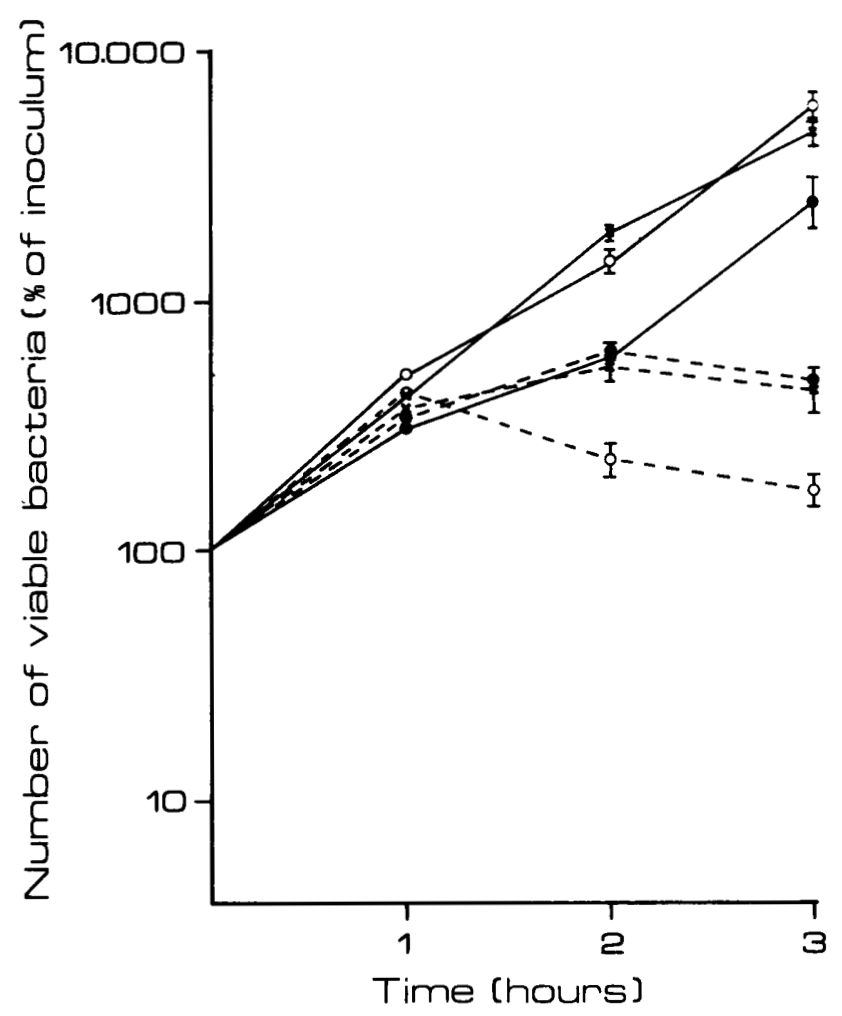

FIG. 2.-Sensitivity of group III E. coli $\mathrm{K}^{+}$strains and their $\mathrm{K}^{-}$mutants after incubation with $15 \%$ normal pooled human serum. - $: \mathrm{K}^{+}$strains; ----: $\mathrm{K}^{-}$strains; $\longrightarrow$ : AD35; $\bigcirc-0:$ AD412; $x \longrightarrow \times: A D 121$. Bars represent the standard deviation of the viable count.

presence of serum. The $\mathrm{K}^{-}$mutants behaved like the parent strains during the first hour. After that time a decrease in viable count was observed, which was more evident for the group II strains. Experiments were done in duplicate and the differences between $\mathrm{K}^{+}$and $\mathrm{K}^{-}$strains were reproducible. No killing of the strains was observed in mouse serum.

\section{Chemiluminescence}

The ability of the strains to activate PMN leucocyte metabolism in the presence of normal human serum was determined by measuring chemiluminescence. The $\mathrm{K}^{-}$ mutants induced greater chemiluminescence than the $\mathrm{K}^{+}$parent strains. The result of one of these experiments is given in fig. 3 as an example. The amount of chemiluminescence was calculated as the mean of the counts after 10,20,30 and 40 min. The difference between $\mathrm{K}^{+}$and $\mathrm{K}^{-}$strains was expressed as the ratio $\mathrm{K}^{+} / \mathrm{K}^{-}$. In table II the $\mathrm{K}^{+} / \mathrm{K}^{-}$ratio of the strains is given for three independent experiments. For all strains the $\mathrm{K}^{+} / \mathrm{K}^{-}$ratio was less than unity, which indicates that $\mathrm{K}^{-}$strains stimulate $\mathrm{PMN}$ leucocytes better than $\mathrm{K}^{+}$strains. The lowest ratio was found for the two $K(A)$ strains and the $\mathrm{K} 1$ strain. 


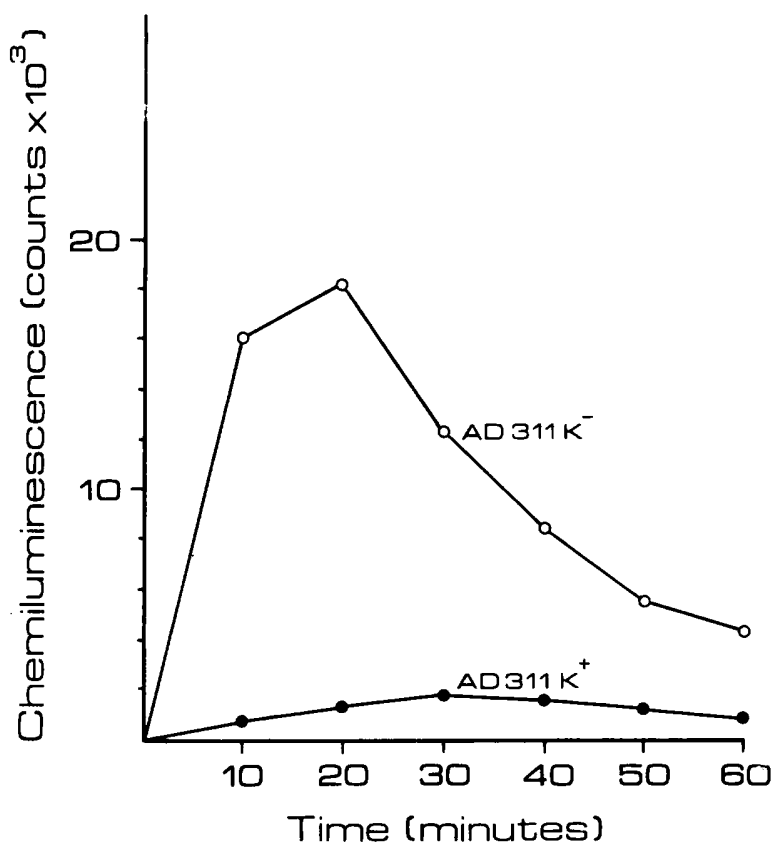

FIG. 3.-Kinetics of chemiluminescence of PMN leucocytes activated by $E$. coli AD311 $\mathrm{K}^{+}$and $\mathrm{AD}^{-} 11 \mathrm{~K}^{-}$.

\section{DisCUSSION}

Much of the evidence for the role of $\mathrm{K}$ antigens as virulence factors in urinary-tract infection has come from epidemiological studies with bacterial strains that differed in many characteristics. Therefore, we decided to study the importance of the $\mathrm{K}$ antigen for nephropathogenicity in an animal model by means of isogenic strains. The only difference that could be detected between the $\mathrm{K}^{-}$mutants and their $\mathrm{K}^{+}$parent strains was the absence of $\mathrm{K}$ antigen. If more than one mutant per strain was isolated the same differences with respect to $\mathrm{K}$ antigen, virulence, serum sensitivity and chemiluminescence were observed. Because the mutants were isolated without mutagenic treatment the occurrence of more than one mutation or deletion in the same strain is unlikely. These factors together strongly indicate that the $\mathrm{K}$ antigen was the only difference between parent and mutant strains. The absence of the $\mathrm{K}$ antigen in the $E$. coli mutants was confirmed by immunoelectrophoresis. These results indicated that the agglutinability of the $\mathrm{K}^{-}$strains with $\mathrm{O}$-antisera was due to the absence of the $\mathrm{K}$ antigen.

Two virulence models were used in this study. The LD50 determination allows a more precise determination of virulence than the model described by van den Bosch et al. (1979) which classifies strains as avirulent (I), nephropathogenic (II) and virulent (III).

The loss of $\mathrm{K}$ antigen resulted in a reduction of virulence in the group III strains, which suggests that the $K$ antigen is an important virulence factor for more general infections in these strains. Whether group III strains came into group I or II after loss of the $\mathrm{K}$ antigen seemed to depend on other virulence factors. It is perhaps not 
surprising that strain AD121, the only group III strain that produced a haemolysin exhibited a nephropathogenic (group II) virulence after loss of the $\mathrm{K}$ antigen, because haemolysin proved to be an important virulence factor for group II strains (van den Bosch et al., 1981; Waalwijk et al., 1982). In the nephropathogenic group II strains, no change in behaviour pattern in the mouse kidney was observed after loss of the $\mathrm{K}$ antigen. From these results we conclude that the $\mathrm{K}$ antigen is of minor importance as a virulence factor for the mouse kidney in this model and with these K-types. These results do not exclude a possible role of $K$ antigens as virulence factors for the urinary tract in an ascending route model, because other virulence factors may be important there.

The LD50 values of two group III strains and one group II strain increased by 3-16 fold after loss of the $\mathrm{K}$ antigen. This confirms the importance of the $\mathrm{K}$ antigen for virulence in these strains, but more experiments with $K(A)$ strains are needed to justify the general conclusion that the $\mathrm{K}(\mathrm{A})$ antigens contribute little to bacterial virulence. The LD50 values of the strains were mostly in agreement with the results of the behaviour pattern experiments except for strains AD35 and AD36. The significant rise in LD50 value of strain AD36 after loss of the $\mathrm{K}$ antigen did not result in a change in behaviour pattern. This may be explained by the fact that in the behaviour pattern experiments bacterial strains were divided into three main groups whereas LD50 determinations permit a more precise estimation of virulence. The LD50 value of strain $\mathrm{AD} 36 \mathrm{~K}$ - increased by a factor of only 3, which may not be enough to change the virulence group. Van den Bosch et al. (1981) have already shown that LD50 values vary by at least a factor of 10 within the three virulence groups. Differences in time to death for group II strains (table II) also support this observation.

The importance of the $\mathrm{K}$ antigen as a virulence factor is often explained by the increased resistance it provides to serum-induced killing and to phagocytosis (Rottini et al., 1975; van Dijk et al., 1977; Horwitz and Silverstein, 1980). In all our K- strains, decreased serum resistance was observed, and all $\mathrm{K}^{-}$strains were better inducers of chemiluminescence in PMN leucocytes. Chemiluminescence is generally used as an indirect measurement of phagocytosis; this indicates that our $\mathrm{K}^{-}$strains were phagocytosed better than our $\mathrm{K}^{+}$strains. It is questionable whether the increased sensitivity to human serum contributes to the decrease in virulence of group III strains in mice, because no killing of any of the strains by mouse serum could be observed (unpublished results). Phagocytosis of the strains by leucocytes, as measured by $\mathrm{CL}$, is probably an important factor that determines the virulence of the group III strains. In the group II strains phagocytosis seems to be of minor importance. It is possible that phagocytosis by human PMNs does not correspond to phagocytosis by mice PMNs.

The observed differences between $\mathrm{K}^{+}$and $\mathrm{K}^{-}$strains in sensitivity to phagocytosis and killing by serum may have several explanations. Hydrophobicity and ability to activate complement in the presence of antibodies or via the alternative pathway may be of great importance. For two strains, AD307 and AD311, higher titres of complement-fixing antibodies against the $\mathrm{K}^{-}$strains in pooled serum were observed, which could explain the differences with these strains. For other strains no differences in titres were found. Possible differences in ability to activate complement via the classical and alternative pathway or in hydrophobicity are currently under investigation. 


\section{REFERENCES}

Ewetz, L., Palmblad, J. AND Thore, A. 1979. Quantitation of phagocytosis by luminol chemiluminescence. In Proceedings of the International Symposium on analytical applications of bioluminescence and chemiluminescence, edited by E. Schram and P. Stanley, State Printing and Publishing Inc., Westgate Village, California, pp. 582-588.

FinNeY, D. J. 1964. Statistical methods in biological assay, 2nd ed., Griffin, London, p. 524.

FREEDMAN, L. R. 1979. Interstitial renal inflammation, including pyelonephritis and urinary tract infection. In Strauss and Welt's Diseases of the Kidney, vol. II, 3rd ed., edited by L. E. Early and C. W. Gottschalk, Little Brown and Company, Boston, pp. 817-876.

GlynN, A. A. AND HowARD, C. J. 1970. The sensitivity to complement of strains of Escherichia coli related to their $\mathrm{K}$ antigens. Immunology, 18, 331-346.

GlynN, A. A., BRumfitt, W. AND HowARD, C. J. 1971. K antigens of Escherichia coli and renal involvement in urinary-tract infections. Lancet, 1, 514-516.

Horwitz, M. A. AND Silverstein, S. C. 1980. Influence of the Escherichia coli capsule on complement fixation and on phagocytosis and killing by human phagocytes. Journal of Clinical Investigation, 65, 82-94.

HowARD, C. J. AND GlynN, A. A. 1971. The virulence for mice of strains of Escherichia coli related to the effects of $\mathrm{K}$ antigens on their resistance to phagocytosis and killing by complement. Immunology, 20, 767-777.

Kalmanson, G. M., Harwick, H. J., Turck, M. and Guze, L. B. 1975 . Urinary tract infection: Localisation and virulence of Escherichia coli. Lancet, 1, 134-136.

KAIJSER, B. 1973. Immunology of Escherichia coli: K antigen and its relation to urinary-tract infection. Journal of Infectious Diseases, 127, 670-677.

McCabe, W. R., Carling, P. C., Bruins, S. AND Greely, A. 1975. The relation of K antigen to virulence of Escherichia coli. Journal of Infectious Diseases, 131, 6-10.

Nicholson, A. M. AND GlynN, A. A. 1975. Investigation of the effect of K antigen in Escherichia coli urinary tract infections by use of a mouse model. British Journal of Experimental Pathology, 56, 549-553.

ØRSKOV, F., ØRSKOV, I., JANN, B. AND JANN, K. 1971. Immunoelectrophoretic patterns of extracts from all Escherichia coli $\mathrm{O}$ and $\mathrm{K}$ antigen test strains. Correlation with pathogenicity. Acta Pathologica et Microbiologica Scandinavica B, 69, 142-152.

Rottini, G., Dri, P., Soranzo, M. R. and Patriarca, P. 1975. Correlation between phagocytic activity and metabolic response of polymorphonuclear leukocytes toward different strains of Escherichia coli. Infection and Immunity, 11, 417-423.

SCHEIDEGGER, J. J. 1955 . Une micro-méthode de l'immuno-électrophorèse. International Archives of Allergy and Applied Immunology, 7, 103-110.

TAYLOR, P. W., RoBerTS, A. P. AND GOWER, P. E. 1972. Evaluation of a technique for the estimation of serum bactericidal activity against gram-negative organisms. Medical Laboratory Technology, 29, 272-279.

VAN DEN Bosch, J. F., DE GRAAFF, J. AND MACLAREN, D. M. 1979. Virulence of Escherichia coli in experimental hematogenous pyelonephritis in mice. Infection and Immunity, 25, 68-74.

VAN DEN Bosch, J. F., Postma, P., DE GraAfF, J. AND Maclaren, D. M. 1981. Haemolysis by urinary Escherichia coli and virulence in mice. Journal of Medical Microbiology, 14, 321-331.

van den Bosch, J. F. Oe, P. L., Postma, P., de Graaff, J., Maclaren, D. M., Jansen, W. H. AND GuINEE, P. A. M. 1980. Virulence of Escherichia coli in acute pyelonephritis, acute cystitis and asymptomatic bacteriuria. Antonie van Leeuwenhoek, 46, 321-329.

van Dijk, W. C., Verbrugh, H. A., Peters, R., van der Tol, M. E., Peterson, P. K. and VERHOEF, J. 1977. Escherichia coli $\mathrm{K}$ antigen in relation to serum-induced lysis and phagocytosis. Journal of Medical Microbiology, 10, 123.

WaAlwiJk, C., van den Bosch, J. F., Maclaren, D. M. and de Graaff, J. 1982. Hemolysin plasmid coding for the virulence of a nephropathogenic Escherichia coli strain. Infection and Immunity, 35, 32-37. 